\title{
Testicular Gonadoblastoma
}

National Cancer Institute

\section{Source}

National Cancer Institute. Testicular Gonadoblastoma. NCI Thesaurus. Code C39911.

A testicular mixed germ cell-sex cord-stromal tumor. It is usually associated with mixed gonadal dysgenesis and ambiguous genitalia. It is characterized by the presence of nests of large neoplastic germ cells and immature cells that resemble Sertoli cells. 